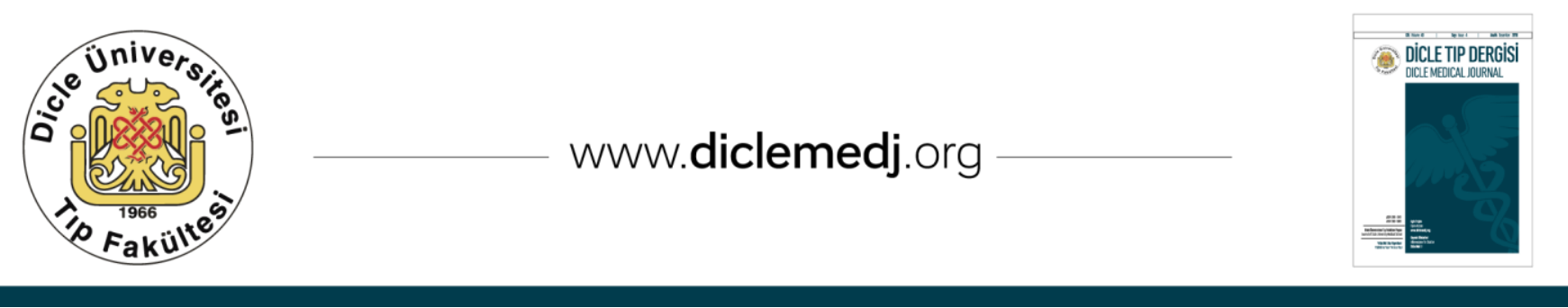

Özgün Araştırma / Original Article

\title{
Investigation of Pepsin in Laryngeal Squamous Cell Carcinoma Specimens
}

\author{
Hamdi Tasli1, Burcu Eser², Hakan Birkent ${ }^{3}$, Burak Asik ${ }^{4}$, Mustafa Gerek ${ }^{5}$ \\ 1 Univ of Health Sci Evliya Celebi Training and Research Hospital Dept of Otolaryngology, Head and Neck Surgery 43000, Kütahya, Turkey ORCID: 0000-0003-2186-5006 \\ 2 Gulhane Medical School, FAVOR-Chromatography Lab. Institute of Health Sciences R\&D Center, Ankara, Turkey ORCID: 0000-0001-5641-3734 \\ 3 Istanbul Cerrahi Hospital Department of Otolaryngology, Head and Neck Surgery, Istanbul, Turkey, 0RCID: 0000-0001-9545-6518 \\ 4 Gulhane Medical School, Department of Otolaryngology, Head and Neck Surgery, Ankara, Turkey, ORCID:0000-0002-1093-8419 \\ 5 Gulhane Medical School, Department of Otolaryngology, Head and Neck Surgery, Ankara, Turkey, ORCID: 0000-0001-8687-2158
}

Received: 03.04.2019; Revised: 04.09.2019; Accepted: 23.09.2019

\begin{abstract}
Objective: Squamous cell carcinoma (SCC) composes $95 \%$ of the carcinoma of the larynx. One of the factor recognized in the past two decades as increasing the risk of SCC is laryngopharyngeal reflux (LPR). The role and mechanism of LPR in laryngeal cancer remain unclear. The aim of this study was to assess the presence of pepsin in laryngeal formalin-fixed, paraffin-embedded (FFPE) squamous cell carcinoma (SCC) specimens in order to test the hypothesis that LPR plays a role in the development of laryngeal SCC.

Method: A total of 29 pathology specimens of advanced-stage laryngeal cancer patients who had undergone total laryngectomy were evaluated. The specimens were confirmed histopathologically as SCC and maintained in paraffin blocks in the pathology department. The western blot (WB) or the enzyme-linked immunosorbent assay (ELISA) analyses were used to measure pepsin enzyme levels.

Results: According to the WB and ELISA analyses, there was no presence of the pepsin enzyme in any of the 29 formalin-fixed, paraffin-embedded (FFPE) laryngeal SCC specimens. However, pepsin was detected with both the WB and the ELISA tests in positive controls and fresh rat stomach specimen.

Conclusion: Pepsin was not present in any of the malignant laryngeal squamous cell carcinoma specimens in this study. Relationship between LPR and laryngeal SCC still remains unclear and further studies are needed to verify the role of pepsin and LPR in laryngeal SCC.
\end{abstract}

Keywords: Laryngopharyngeal reflux; laryngeal carcinoma; pepsin; larynx. 


\section{Larenks Skuamöz Hücreli Karsinom Örneklerinde Pepsin Araștırılması}

\section{Öz}

Amaç: Skuamöz hücreli karsinom (SHK) larenks kanserlerinin \% 95'ini olușturur. Son yirmi yılda SHK riskinin artmasında kabul gören faktörlerden biri larengofaringeal reflü hastalığıdır (LFR). Larenks kanserinde LFR'nin rolü ve mekanizması belirsizliğini korumaktadır. Bu çalışmanın amacı, larenks kanseri gelişiminde LFR'nin rol oynadığı hipotezini test etmek için larengeal formalinle fikse edilmiş parafine gömülü (FFPG) skuamöz hücreli karsinom (SHK) örneklerinde pepsin varlığını araştırmaktır.

Yöntemler: Total larenjektomi uygulanan ileri evre larengeal kanser hastalarının toplam 29 patoloji örneği değerlendirildi. Patoloji bölümünde parafin bloklarında tutulan örneklerin histopatolojik olarak SHK olduğu doğrulandı. Pepsin enzim seviyelerini ölçmek için western blot (WB) veya enzime bağlı immunosorbent assay (ELISA) testleri kullanıldı.

Bulgular: WB ve ELISA test sonuçlarına gore, 29 formalinle fikse edilmiş, parafine gömülü (FFPG) larengeal SHK örneklerinin hiçbirinde pepsin enzimine rastlanmadı. Bununla birlikte, pozitif kontrollerde hem WB hem de ELISA testleri ile pepsin enzimi tespit edildi.

Sonuçlar: Bu çalışmada malign larengeal skuamöz hücreli karsinom örneklerinde pepsine rastlanmadı. LFR ve larengeal SHK arasındaki ilișki hala belirsizliğini korumakla birlikte larengeal SHK'da pepsin ve LFR'nin rolünü doğrulamak için daha ileri çalışmalara ihtiyaç duyulmaktadır.

Anahtar kelimeler: Larengofarengeal reflü, larenks kanseri, pepsin, larenks

\section{INTRODUCTION}

Carcinoma of the larynx constitutes $30 \%$ to $50 \%$ of the cancers diagnosed in the head and neck region ${ }^{1,2}$. It is an aggressive tumor with an approximately $60 \% \quad 5$-year survival rate $^{3}$. Squamous cell carcinoma (SCC) composes $95 \%$ of the carcinoma of the larynx. The major independent risk factors proven thus far are lifestyle factors, such as tobacco and alcohol ${ }^{4}$. Factors recognized in the past two decades as increasing the risk of cancer are genetic predisposition, dietary deficiencies, occupational factors, viral infections, and laryngopharyngeal reflux (LPR) ${ }^{5}$.

LPR is defined as the backflow of the gastric contents beyond the esophagus, up to the laryngopharyn $\mathrm{x}^{6}$. The gastric contents primarily responsible for LPR pathogenesis are gastric acid and pepsin. Pepsin is the primary proteolytic enzyme of the digestive system and is posited to be a reliable clinical marker for the diagnosis of LPR. Pepsin can be easily detected in tissue specimens or swab samples of the laryngopharynx using immunologic methods such as the western blot (WB) or the enzyme- linked immunosorbent assay (ELISA) ${ }^{6}$. LPR is associated with various otolaryngological pathologies, such as globus pharyngeus, dysphonia, dysphagia, chronic throat-clearing, posterior laryngitis, laryngeal granulomas, and subglottic stenosis ${ }^{7}$. In 1960, Gabriel and Jones ${ }^{8}$ first suggested that LPR may also be a potential risk factor for laryngeal SCC and that chronic irritation caused by acid reflux may lead to a malignant change in the laryngopharyngeal mucosa. Since then, many clinical studies have shown an association between LPR and laryngeal cancer, but some studies suggesting the opposite are also available ${ }^{9}$. The role and mechanism of LPR in laryngeal cancer remain unclear due to the confounding roles of smoking and alcohol consumption, suboptimal study designs, and inaccurate diagnostic tools ${ }^{10}$.

The objective of the present study was to investigate the presence of pepsin in laryngeal formalin-fixed, paraffin-embedded (FFPE) SCC specimens in order to test the hypothesis that LPR plays a role in the development of laryngeal SCC. 


\section{METHOD}

\section{Patients and Specimens}

A total of 29 pathology specimens of advancedstage laryngeal cancer patients who had undergone total laryngectomy between September 2010 and August 2015 were evaluated. The study was carried out according to the Declaration of Helsinki and had been previously approved by the local review board (2015-37). At first a written informed consent was taken from each of the patients. The specimens were confirmed histopathologically as SCC and paraffinized in pathology laboratory. The WB and ELISA tests were used to detect pepsin enzyme in tissues taken from the malignant laryngeal samples. To assess the accuracy of the method, the presence of pepsin in positive controls was also investigated with WB and ELISA.

The preoperative flexible laryngoscopic examination images of all the patients were assessed by an otolaryngologists. Signs of LPR were evaluated with the reflux finding score $(\mathrm{RFS})^{11}$. RFS is a clinical index consisting 8-item scale which is often preferred to identify the presence of LPR and document it's severity. The scale ranges from 0 (no abnormal findings) to a maximum of 26 (worst score possible). Statistically, an individual with a RFS greater than 7 has LPR.

Exclusion criteria included the following: diagnosis of of early stage laryngeal cancers, or any malignancies despite laryngeal squamous cell carcinoma, history of previous stripping, cordectomy, or partial laryngectomy, and head and neck radiotherapy.

\section{Western Blot (WB) Analysis}

After the deparaffinization, total protein was removed from the tissue samples in a RIPA lysis buffer (sc-24948, Santa Cruz Biotechnology, Santa Cruz, California). Following the steps of homogenization and centrifugalization, the supernatants were examined to find out pepsin with immunologic methods (WB and ELISA) and protein content was evaluated with the Bradford assay. Twenty microgram total protein was taken from each sample. The proteins were placed in a $10 \%$ sodium dodecyl sulfate-polyacrylamide gel electrophoresis (SDS-PAGE) gel appropriately to standard SDS-PAGE protocol, and moved to a polyvinylidene fluoride membrane (GE Healthcare, Piscataway, NJ). After this stage, the proteins were brought together with mouse monoclonal antibodies (sc-101405 Pepsin A (2F5), Santa Cruz Biotechnology, Inc., Santa Cruz, California). In addition, positive and negative controls were examined with the samples to demonstrate that the method is correct. The blots were analyzed with alkaline phosphatase conjugated secondary antibody diluted 1:5,000 (Invitrogen Corporation, CA, USA). At last, the blots were submitted to increased chromogenic substrate reagents (sc2048, Santa Cruz Biotechnology, Santa Cruz, California) and they were evaluated by radiography. If any amount of band is detected, it is revealed that there is pepsin in the samples ${ }^{12}$.

\section{Enzyme-Linked Immunosorbent Assay (ELISA) Analysis}

The pepsin assay works according to sandwich enzyme-linked immunosorbent assay (ELISA) principle. First, $100 \mu \mathrm{l}$ of protein was obtained from malignant tissue specimens and placed into the microplate wells of an ELISA kit (SN:201-12-0923, Human Pepsin, PP ELISA Kit, SunRedBio/Baoshan District/Shangai). This stage allowed the target antigen to bind to a biotin-conjugated detection antibody by maintaining incubation for 90 minutes at $37^{\circ} \mathrm{C}$. After washing the proteins, a streptavidinhorseradish peroxidase (HRP) conjugate was added to bind with biotin. In the next step, after addition of Tetramethylbenzidine (TMB) to HRP, a reaction started resulting in color 
development. Wavelength of the color was determined at 450 nanometers and compared to a reference curve ${ }^{12}$.

\section{Statistical analyses}

The data were analyzed using Statistical Package for Social Sciences software (SPSS 17.0 for Windows; SPSS Inc., IL, USA). The results were evaluated by means of the number (percentage) of patients, mean, and standard deviation.

\section{RESULTS}

This study investigated 29 malignant pathology specimens of advanced-stage laryngeal cancer patients who had undergone total laryngectomy. 27 (93.1\%) were male, 2 (6.8\%) were female, and the mean age was $62.27 \pm$ 7.71 (48-76). A total of 26 (89\%) patients were using tobacco while $3(10 \%)$ patients were not. The mean RFS score of the patients was 18.58 \pm 1.95 (16-23) (Table 1).

The pathology results revealed that squamous cell carcinoma was detected in all the laryngeal tissues. Of the 29 specimens, 4 (13.7\%) were well differentiated, $19 \quad(65.5 \%)$ were moderately differentiated, and $6(20.6 \%)$ were poorly differentiated. Pathology showed that $24(82.7 \%)$ of the malignant laryngeal tissues were glottic, 4 (13.7\%) were supraglottic and glottic, and 1 (3.4\%) was transglottic. According to TNM classification, there were no stage $\mathrm{T} 1$ or $\mathrm{T} 2$ specimens but 17 (58.6\%) were stage T3 and 12 (41.3\%) were stage T4. An evaluation of the lymph nodes' $\mathrm{N}$ stage showed $24(82.7 \%)$ patients were N0, 3 (10.3\%) patients were $\mathrm{N} 1$, and $2(6.8 \%)$ patients were N2. In addition, 5 (17.2\%) of the specimens showed extracapsular spread, 6 (20.6\%) showed perivascular-perineural invasion, and 5 $(17.2 \%)$ showed positive surgical margins (Table 1).

According to the WB and ELISA analyses, there was no presence of the pepsin enzyme in any of the 29 formalin-fixed, paraffin-embedded
(FFPE) laryngeal SCC specimens. (Figure 1, 2) However, pepsin was detected with both the WB (Figure 3) and the ELISA (Figure 2) tests in positive controls. While ELISA positive controls consist of pepsin samples with different molecular weight calibrators, WB positive controls included fabricated protein marker samples with equivalent molecular weight of pepsin, and these samples were used to confirm the availability of the ELISA and WB devices for evaluation of pepsin enzyme. Since the positive control samples used in the present study were not obtained from the patients, any diagnostic confirmation for control group was performed.

\section{DISCUSSION}

Laryngopharyngeal reflux (LPR) is defined as the retro-grade movement of gastric contents at the level of the laryngopharynx ${ }^{6}$. Basic stomach contents moving to the laryngopharynx, gastric acid and pepsin, play a crucial role in pathophysiology by initiating mucosal inflammation and a wide range of immune responses in the airway mucosa ${ }^{9}$. It has been recently demonstrated that when the gastric proteolytic enzyme pepsin reaches the laryngopharynx as a result of LPR disease, the laryngeal epithelial cells maintain the enzyme at endosomes at a $\mathrm{pH}$ of 5 , pepsin becomes active, and cell damage starts. Approximately $40 \%$ of pepsin's maximal activity occurs at this $\mathrm{pH}^{13}$. Johnston et al. ${ }^{14}$ have recently shown that pepsin proteins with a $\mathrm{pH}$ of 7 may also become reactivated inside the cell and cause cell damage. Pepsin damages cellular membrane proteins and disturbs the permeability of the membrane, leading to corruption of ion and water transport and resulting in cell death. When reflux occurs, anti-reflux barrier dysfunction increases and a vicious cycle of reflux and cell damage is perpetuated ${ }^{15}$. 
Table 1. The demographic characteristics of patients, histopathological and morphological features of laryngeal formalin-fixed, paraffin-embedded (FFPE) malignant tissues and immunological assessment of the presence of pepsin enzyme.

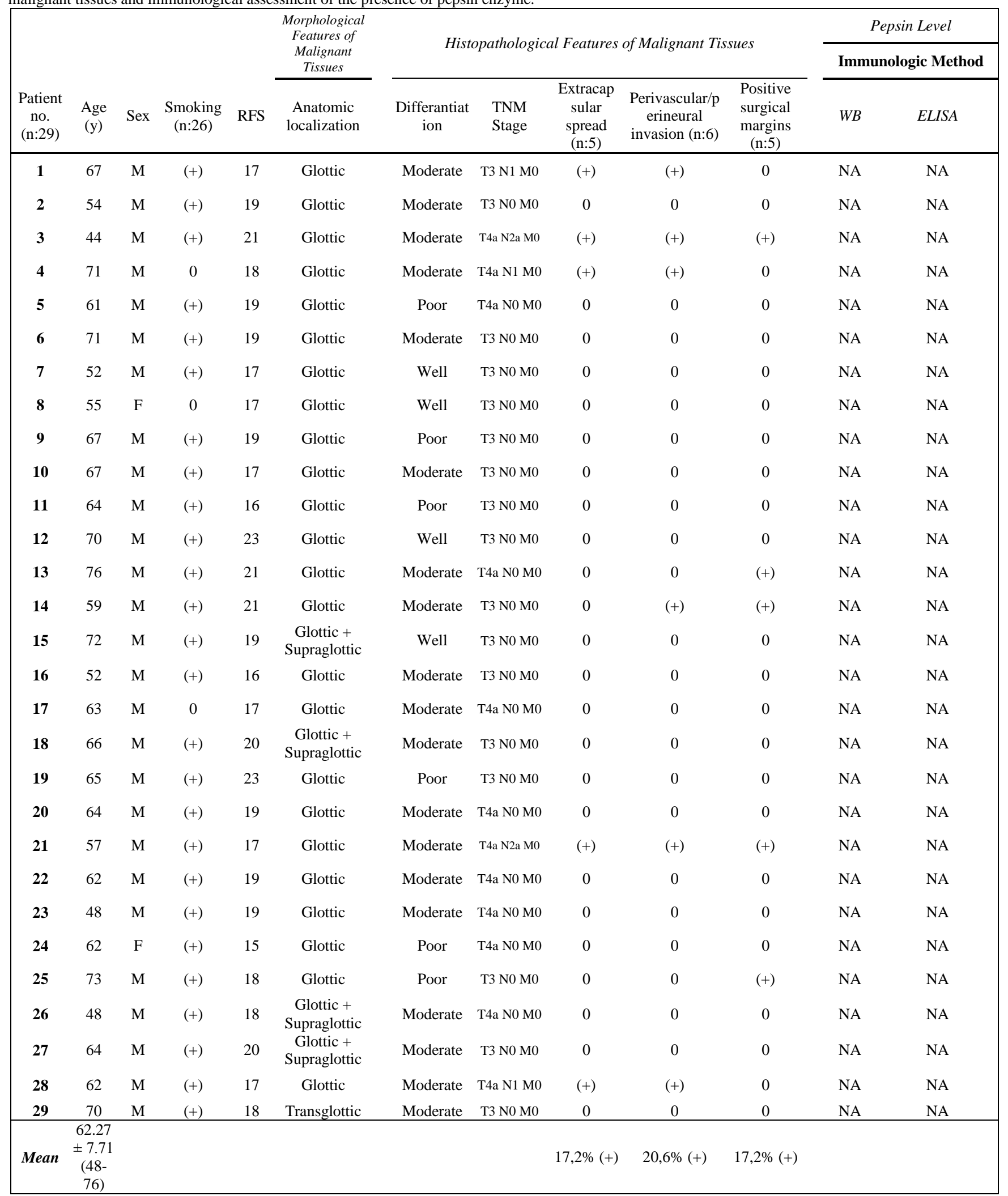


Additionally, common exogenous agents such as voice abuse, smoking, chronic cough, vomiting, and recurrent infections provoke the inflammatory process and this likely supports the multifactorial effect.

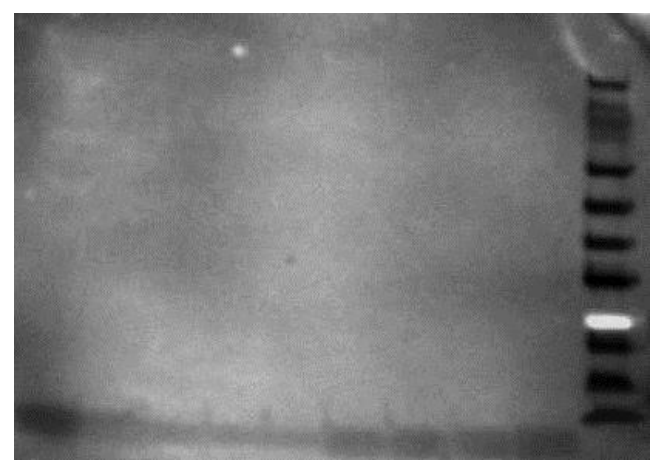

Figure 1. According to $W B$ analysis there was no presence of pepsin enzyme in malignant laryngeal tissue samples.

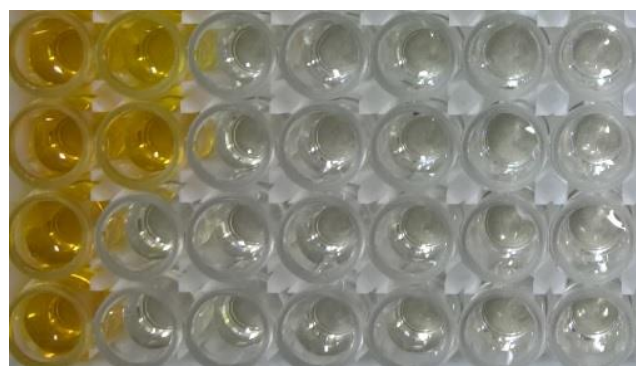

Figure 2. According to ELISA analysis, dark yellow colored wells showed the presence of pepsin enzyme in positive controls; white colored wells indicate that no pepsin enzyme was detected in laryngeal formalin-fixed, paraffin-embedded (FFPE) malignant tissues.

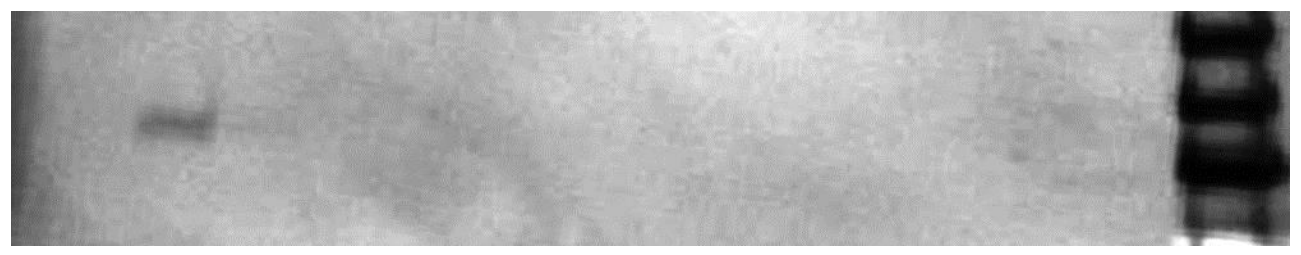

Figure 3. According to WB analysis pepsin enzyme was detected in positive controls (Pepsin bant was observered in WB gel).

Many studies have stressed that reflux could lead to malignant changes on the mucosa of the laryn $\mathrm{x}^{16}$. Until now, the literature on the relationship between reflux and larynx cancer have reached differing and, at times, opposite conclusions. Nilsson et al. ${ }^{17}$ investigated 66,695 patients diagnosed with gastroesophageal reflux disease (GERD) in a cohort study. Of this population, only 30 laryngeal cancer patients were found during the follow-up period and the study concluded that there was no association between reflux disease and larynx cancer ${ }^{17}$. Francis et al. ${ }^{18}$ evaluated 14,449 larynx cancer patients and 14,449 controls in a case-control study finding that alcohol consumption and smoking were independent risk factors but reflux was not. There are also prospective studies showing no association between reflux and larynx cancer. In studies performed by Ozlugedik et al. ${ }^{19}$ and Geterud et al. ${ }^{20}$ it was concluded that reflux is not an independent risk factor for larynx cancer. Conversely, some studies have suggested the opposite, showing an association between reflux and laryngeal cancer. El-Serag's ${ }^{21}$ case-control study compared 9,292 laryngeal cancer patients to 37,168 controls without cancer. Patients with reflux were reported to have a higher risk of cancer and it was independent of age, sex, smoking and alcohol consumption ${ }^{21}$. Similarly, Qadeer et al. ${ }^{22}$ published a meta-analysis, concluding that patients with reflux were under 2.37 times higher than the control group and 
reflux is a risk factor in the pathogenesis of laryngeal carcinoma.

The controversy here can be blamed on these studies' limitations, the major limitations being as follows: limited or incomparable control and study groups, deficiencies in the retrospective analyses, requirement of invasive tests on prospective studies, improper patient selections, and absence of consensus on diagnostic criteria with lack of diagnostic tests $^{23}$. Immunologic methods such as the WB and the ELISA easily detect pepsin in tissue specimens or swab samples of the laryngopharynx and may be used as diagnostic tools for LPR ${ }^{6}$. The sensitivity and specificity of an ELISA, which can reach up to $100 \%$ and $89 \%$, respectively, depend on the characteristics of the antibodies employed. As cross-reaction occurs with pepsinogen on many of the pepsin proteins, WB is recommended as the alternative immunologic test to improve specifity $^{6}$. Kim at al. ${ }^{24}$ performed a WB on sputum and saliva samples for LPR diagnosis; the sensitivity and specificity were $89 \%$ and $68 \%$, respectively. This study employed both the ELISA and the WB immunologic methods to determine the pepsin enzyme in biopsy specimens. The specimens were paraffinized and confirmed histopathologically as laryngeal SCC, a component unique to this study.

The WB and ELISA analyses revealed that there was no pepsin in any of the 29 malignant laryngeal cancer tissues. The absence of the pepsin in any of the malignant laryngeal cancer tissues raises the question of whether it is possible to detect pepsin in the larynx, particularly in FFPE tissues. It has been reported that the pepsin enzyme can be easily detected in laryngeal biopsy materials by immunological methods. Johnston et al. ${ }^{25}$ detected pepsin in 5/9 (55\%) of laryngeal cancer biopsy specimens but could not detect pepsin in a healthy control group. The present study investigated the presence of pepsin in positive controls in order to confirm the accuracy of the methodology and pepsin was detected in them.

Another question raised in the study was whether pepsin would be present in FFPE tissue. In 1991, Shi et al. ${ }^{26}$ were the first to describe the antigen retrieval (AR) technique of extracting proteins from FFPE tissues for immunohistochemical analysis. Historically, most studies accept that proteins can be can be separated from FFPE tissues by AR methods and can be suitable for proteomic analysis, as there is a reported up to $90 \%$ overlap of proteins in FFPE and fresh tissues from the same specimen ${ }^{27}$. The fact that pepsin is not found can be explained by this small overlap ratio. In addition, fixation time plays a critical role in extraction quality and success. Ostasiewicz et al. ${ }^{28}$ compared proteomes from two tissue samples of the same liver, one fixed overnight and one for 5 days, and found that $82 \%$ of the proteins were similar. They determined that over-fixed samples were negatively affected almost $7 \%$ on average and suggested that the fixation duration likely influences the FFPE proteome profile ${ }^{28}$. In the present study, specimens remained in the formalin solution between 3 and 18 hours before paraffinization; the specimens' proteome profile may have been affected during this period. Furthermore, the "age" of the FFPE specimen may affect the success of extraction; however, the literature concludes that storage time appears considerably less detrimental to extraction success than fixation time. Balgley et al. ${ }^{29}$ compared two tissue blocks, one 30 years old and one 6 years old, with no significant differences in proteome coverage detected between the two groups. In this study, the specimens were maintained for $3,66 \pm 1,86$ years, possibly an insignificant factor in the absence of pepsin enzyme in malignant laryngeal tissues. Finally, further immunological studies on fresh samples may help to reveal the relationship between laryngeal cancer and reflux in the future. 


\section{Limitations}

The major limitation of this study is the uncertainty in diagnostic tools of LPR. Ambulatory, 24-hour, double-probe $\mathrm{pH}$ monitoring, and upper digestive system endoscopy are frequently used and a crucial diagnostic tool of LPR; however, it is demonstrated comformance of proximal $\mathrm{pH}$ testing to be as low as 55\% for patients with $\mathrm{LFR}^{30}$. Despite absence of this diagnostic tool, high RFS results confirmed the presence of LPR. Another handicap is possible negative effect of the laryngeal squamous cell carcinoma on evaluation of RFS. However, fiberoptic endoscopic laryngeal examinations of the patients showed that laryngeal cancer did not alter the endoscopic examination of healthy sides, and especially postcricoid region, so RFS was performed correctly.

\section{CONCLUSION}

Pepsin was not present in any of the malignant laryngeal squamous cell carcinoma specimens in this study. Relationship between LPR and laryngeal SCC still remains unclear and further studies are needed to verify the role of pepsin and LPR in laryngeal SCC.

This study was presented as a poster at the American Head and Neck Society (AHNS) meeting (Seattle, WA, USA) between July 16-20, 2016.

Conflict of Interest: The authors have no conflict of interest to declare.

Financial Disclosure: This study was supported by Gülhane Medical School (AR2014/48).

Informed Consent: Written informed consent was obtained from patients who participated in this study.

Peer-review: Externally peer-reviewed.

Ethics Committee Approval: Ethics committee approval was received for this study from the Ethics Committee of Gülhane Medical School (2016/37; Date: 05/06/2014).

\section{REFERENCES}

1. Cann CI, Fried MP, Rothman KJ. Epidemiology of squamous cell cancer of the head and neck. Otolaryngol Clin North Am. 1985; 18: 367-88.

2. Landis SH, Murray T, Bolden S, et al. Cancer statistics, 1998. CA Cancer J Clin. 1998; 48: 6-29.

3. Berrino F. Survival of cancer patients in Europe: the EUROCARE-2 study. IARC Sci Publ. 1999; 151: 1-572.

4. Rothman KJ, Cann CI, Flanders D, et al. Epidemiology of laryngeal cancer. Epidemiologic reviews. 1980; 2: 195209.

5. Copper MP, Smit CF, Stanojcic LD, et al. High incidence of laryngopharyngeal reflux in patients with head and neck cancer. Laryngoscope. 2000; 110: 1007-11.

6. Samuels TL, Johnston N. Pepsin as a Marker of Extraesophageal Reflux. Ann Otol Rhinol Laryngol. 2010; 119: 203-8.

7. Wassenaar E, Johnston N, Merati A, et al. Pepsin detection in patients with laryngopharyngeal reflux before and after fundoplication. Surg Endosc. 2011; 25: 3870-6.

8. Glanz H, Kleinsasser 0 . Chronic laryngitis and carcinoma. Arch Otorhinolaryngol. 1976; 212: 57-75.

9. Johnston N, Yan JC, Hoekzema CR, et al. Pepsin promotes proliferation of laryngeal and pharyngeal epithelial cells. Laryngoscope. 2012; 122: 1317-25.

10. Qadeer MA, Colabianchi N, Vaezi MF. Is GERD a risk factor for laryngeal cancer?. Laryngoscope. 2005; 115: 486-91.

11. Belafsky PC, Postma GN, Koufman JA. The validity and reliability of the reflux finding score (RFS). Laryngoscope. 2001; 111: 1313-7.

12. Tasli H, Eser B, Asik MB, et al. Does Pepsin Play a Role in Etiology of Laryngeal Nodules?. J Voice. 2018 May 11. pii: S0892-1997(18)30041-9.

13. Johnston N, Dettmar PW, Bishwokarma B, et al. Activity/stability of human pepsin: implications for reflux attributed laryngeal disease. Laryngoscope. 2007; 117: 1036-9.

14. Johnston N, Wells CW, Samuels TL, et al. Rationale for targeting pepsin in the treatment of reflux disease. Ann Otol Rhinol Laryngol. 2010; 119: 547-58. 
15. Johnston N, Peter W. Dettmar PW, et al. Laryngopharyngeal reflux and GERD. Ann N Y Acad Sci. 2013; 1300: 71-9.

16. Coca-Pelaz A, Rodrigo JP, Takes RP, et al. Relationship between reflux and laryngeal cancer. Head Neck. 2013; 35: 1814-8.

17. Nilsson $M$, Chow $W H$, Lindblad $M$, et al. No association between gastroesophageal reflux and cancers of the larynx and pharynx. Cancer Epidemiol Biomarkers Prev. 2005; 14: 1194-7.

18. Francis DO, Maynard C, Weymuller EA, et al. Reevaluation of gastroesophageal reflux disease as a risk factor for laryngeal cancer. Laryngoscope. 2011; 121: 102-5.

19. Ozlugedik S, Yorulmaz I, Gokcan K. Is laryngopharyngeal reflux an important risk factor in the development of laryngeal carcinoma? Eur Arch Otorhinolaryngol. 2006; 263: 339-43.

20. Geterud A, Bove M, Ruth M. Hypopharyngeal acid exposure: an independent risk factor for laryngeal cancer?. Laryngoscope. 2003; 113: 2201-5.

21. el-Serag HB, Sonnenberg A. Comorbid occurrence of laryngeal or pulmonary disease with esophagitis in United Steates militery veterans. Gastroenterology. 1997; 113: 755-60.

22. Qadeer MA, Colabianchi N, Vaezi MF. Is GERD a risk factor for laryngeal cancer?. Laryngoscope. 2005; 115: 486-91.

23. Galli J, Cammarota G, Calò L, et al. The role of acid and alkaline reflux in laryngeal squamous cell carcinoma. Laryngoscope. 2002; 112: 1861-5.
24. Kim TH, Lee KJ, Yeo M, et al. Pepsin detection in the sputum/saliva for the diagnosis of gastroesophageal reflux disease in patients with clinically suspected atypical gastroesophageal reflux disease symptoms. Digestion. 2008; 77: 201-6.

25. Johnston N, Yan JC, Hoekzema CR, et al. Pepsin promotes proliferation in normal and transformed laryngopharyngeal epithelial cells. Laryngoscope. 2012; 122: 1317-25.

26. Shi SR, Key ME, Kalra KL. Antigen retrieval in formalin fixed, paraffin-embedded tissues: an enhancement method for immunohistochemical staining based on microwave oven heating of tissue sections. J Histochem Cytochem. 1991; 39: 741-8

27. Tanca A, Pagnozzi D, Addis MF. Setting proteins free: progresses and achievements in proteomics of formalin-fixed, paraffin-embedded tissues. Proteomics Clin Appl. 2011; 6: 7-21.

28. Ostasiewicz P, Zielinska DF, Mann M, et al. Proteome, phosphoproteome, and N-glycoproteome are quantitatively preserved in formalin-fixed paraffinembedded tissue and analyzable by high-resolution mass spectrometry. J Proteome Res. 2010; 9: 3688700 .

29. Balgley BM, Guo T, Zhao K, et al. Evaluation of archival time on shotgun proteomics of formalin-fixed and paraffin-embedded tissues. J Proteome Res. 2009; 8: $917-25$.

30. Vaezi ME, Schroeder PL, Richter JE. Reproducibility of proximal probe $\mathrm{pH}$ parameters in 24-hour ambulatory esophageal pH monitoring. Am J Gastroenterol. 1997; 92: 825-9. 